\title{
The Involvement of Women and Children in the Bombing Attack in Indonesia
}

\author{
Anik Farida $^{1}$, Zakiyah $^{2}$, Koeswinarno $^{3}$

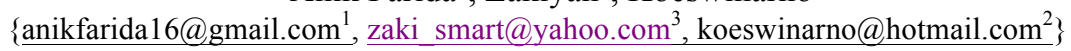

\begin{abstract}
Center for Policy Research, Board for Research and Development and Books, Ministry of Education and Culture ${ }^{1,}$ Office of Religious Research and Development, Ministry of Religious Affairs, Semarang, Indonesia ${ }^{2,3}$
\end{abstract}

\begin{abstract}
This paper discusses women and children involvement in the terrorism in Indonesia. As it is the fact that in the first half of the 2018 there was bombing attack in Surabaya and Sidoarjo East Java involving women and children as the main actors. This action marks as a new strategy of terrorist group in Indonesia to employ them as the martyr of their battle. Indonesia has experiences a series of bombing attacks for many years with the men as the main perpetrators. In the past, women in the jihadist group are usually as the housewife and nurturing their children as well as supporting their husband by providing logistic. Data of this article was collected using interview, observation and documentary research. Findings of this study shows that nowadays, using women as the martyr was an effective way to gain the terrorism goal for the following reasons; firstly, women have skills to transfer their knowledge to their children including the radical thought, therefore all member of the family are involved in the bombing actions. Secondly, women are less suspected than men; therefore they will freely attack at the public sphere. Thirdly, women can play many roles in the terrorism act both in the back and the front line of actions. Furthermore, this study also found that the daily performances of those actors of terrorism are similar of common people and they interact with their neighbors in which this different from the past where generally terrorist families live as a "closed" group.
\end{abstract}

Keywords: Women and children in terrorism, bombing attack, suicide bombing.

\section{Introduction}

In the first half of 2018 Indonesia faced a series of terrorism act that were done by a terrorist group. It was started with the attack at Mako Brimob and the suicide bombing at three different churches in Surabaya East Java and then followed by another suicide bombing at the front gate of police office in Surabaya and at a Rusunawa (a very modest flat) in Sidoarjo East Java [1]. In these East Java incidents, there are women and children involved in those terror attacks. This case is the first action in which women and children engaged in the suicide bombing and terrorism in Indonesia.

The involvement of women in terrorism in Indonesia is actually begun a long time ago; however they were not as the persons in the front line of the terror attack. There were many cases as reported here; firstly, in June 2005, Mumfiatun, the second wife of Nurdin M Top 
(the terrorist) was sentenced three years imprisonment. She was sentenced for hiding her husband as a terrorist. She knew that her husband was hunted by police as the terrorist suspect and knew where her husband hide, but she did not report him to the police. Her silent and her action made her husband did further terror action freely. Secondly, Inggrid Wahyu Cahyaningsih, Nina, Dewi, and Ubaedah are among eleven women arrested by police criminal team of Polda Jaya (police squad of Jakarta province) in 2004. These four women are suspected associated with the Cimanggis terrorist attack. Then, one of those women named Inggrid was continued to be proceed at the prosecution office. Thirdly, Putri Munawaroh, the wife of Susilo Adib alias Hasan who hide Nordin M Top for three months in their house. At that time, Nordin M Top was hunted by police because he was involved in the bombing attack at JW Marriot hotel and Ritz Carlton hotel in Jakarta in 2009. For those months, Putri Munawaroh served Noordin M Top with food and drink until they were arrested by Densus 88. Then, she was detained for ten years started from 29 July 2010 because she hided the terrorist suspect.

Fourthly, in the mid August 2013 Jakarta Police arrested a woman from Aceh, she was accused as selling water soft gun illegally in Cimanggis Depok West Java. During that apprehending, police seized weapon type automatic colt caliber 25 . From the investigation, it was detected that she was the wife of Abu Sofyan, a terrorist detainee who was sentenced for ten years custody; he was jailed for selling weapon to the terrorist network in Aceh [2]. Fifthly, a study done by[3] mentioned the involvement of women in the terrorism. In his writing, [3]discussed about Paridah, the wife of Mukhlas, one of the Bali bombing actors; Mukhlas was also a former fighter in Afghanistan. She was married with Mukhlas arranged by her father. After this marriage, Mukhlas indoctrinated her wife with the radical teaching for almost a month. Then, Paridah become one of the followers of the Islamic radical group. It is said that a housewife in the radical group, besides as the "bearer" of children, she becomes a teacher for her children, so that in the future those kids will be fighters. They teach their children abide by the teaching given by their husband. This is an important step since these children will become future fighters in the battlefield and continue their parents' struggles. At the same time, the role of women becomes significant to build their children characters [3].

All those women played significant roles in supporting their husband's doing, however they did not play role in the front line as amartyr. Munfiatun, Putri Munawiroh, Inggrid and Paridah as well as other women have knowledge of Islamic radical teaching and they encourage their husband to engage as mujahid (combatant at a war zone). Those housewives and women are usually responsible to take care of their husband and their children as well as to encourage them to take a part in the battle. In addition, women provide logistic for their husband and encourage them to be brave during the warfare.

The participation of women and children as martyr in the terrorism action is a new phenomenon in Indonesia, although, there is previous action done by women without children related to terrorism. Firstly, Dian Yulia Novi (28 years) is the first woman in Indonesia who tried to be a "bride", a term for the suicide bomber. She planned to explode herself with bomb at the president palace. Her plan was failed; she was arrested by Densus 88 (A special anti terror squad) in 10 December 2016 in Bekasi West Java. She was a migrant worker who had worked in Taiwan from 2013 to 2016 . She was sentenced for 7.5 years of detention. This punishment was shorter than the initial demand asked by the prosecutor in which they asked for 10 years imprisonment. She was reported as affiliated with Bahrun Naim, the Bombing actor at Thamrin street Jakarta in 2016. She was suspected as influenced by ISIS doctrine mentioning that there will be terror in Indonesia, if she could not go to Syria. Secondly, Ika Puspitasari alias Salsabila was arrested in December 2016 as she was planned to explode 
bomb in Bali. She was initially a migrant worker in Hong Kong. She was sentenced for 7.5 years detention as she found guilty for providing money for her husband activity related to ISIS activities in Syria. She was eagerly supporting jihad activity, in which she was tried to be "bride" but she failed (Utama, 2017; Purnama, 2016).

The case of women and children (family) as the actor of terrorism then becomes an interesting fact, since this is a new phenomenon in Indonesia. Bombing case in Surabaya marks as a new history of terrorism development in this country. Therefore, it is important to study this theme. This article explores this issue starting with the discussion of the chronology of the bombing incidence in Surabaya and Sidoarjo East Java. It is continued with the discussion of how the involvement of women and family is considered as an effective way to reach their goal compare to the male actors.

When discussing women in the terrorism network issues, women are both victims and actors at the same time. Culturally, in a patriarchal culture, women are very obedient to their husbands in any condition. Marrying women is one of the modes to recruit women to be involved in the terrorism group. In addition, many women are considered more susceptible to be influenced, especially those who have problems in their family and economy. Using women in the terror attack also has strategic-tactical aspects; this is because women as perpetrators of terror will deceive law enforcement officials, so that the perpetrators of terror are identical to men.

The very massive propaganda done by terrorist network and the recruitment model through social media gives hope for women to move to areas where the terrorism network is developing. This is because they feel that the network can accommodate various grievances, dissatisfaction with living under un-Islamic values, a sense of injustice in their home country, the desire to enjoy life under the Islamic state as part of amaliyah and the economic promise of a high salary and all the tantalizing free facilitie.

\section{Research Method}

This article was written based on a research done in 2018. This is a qualitative case study focusing on the case of suicide bombing in Surabaya and bomb explosion in Sidoarjo East Java Indonesia happened in May 2018. Data was collected by employing three different methods namely; (a) interview; it was done with the relevant key persons, primary and secondary informants including police officers, forensic police team, pastors, management team of three churches in Surabaya, government officers, neighbors of the terrorists, village administrators, and people living around the terrorists' house. This interview was conducted to search data related to these elements; the chronology of the incidents, and the backgrounds of the terror actors and their family. (b) Observation; in this phase researchers observed the place of bomb explosion in three churches and Rusunawa in Surabaya and Sidoarjo as well as observed the neighborhood where the terrorists live. (c) Library research; this method was utilized to seek the written document related to the topic of this study. This includes reports from the online newspaper and magazine, previous research reports, articles from the academic journals, books and other related documents. 


\section{Result And Discussion}

\subsection{Chronology of Bomb Explosion in Surabaya and Sidoarjo East Java}

On Sunday morning, 13 May 2018, there were bomb blast at three churches in Surabaya, at Church Santa Maria Tak Bercela, church Pantekosta Pusat Surabaya (GPPS) Sawahan, Gereja Kristen Indonesia (GKI-church). The first detonation happened in Church Santa Maria Tak Bercela in Ngagel Madya street Gubeng Surabaya at 07.13 WIB (Western Indonesian standard time), and about five minute later the second bomb explosion occurred in GKI-church at Diponegoro street Surabaya, and then at around 07.50 WIB the third bomb exploded at GPPS in Arjuno street Surabaya.

All the terror actors at those three churches are death. Based on the identification done by a police forensic team (INAFIS), East Java, it is identified that all of them are related as a family. Here is the list of the perpetrators; Dita Oeprianto (47 years old), PujiKuswati (43 years old), Yusuf Fadhil (18 years old, a boy), Firman Halim (16 years old, a boy), Fadhila Sari (12 years old, a girl), and Famela Rizqita (9 years old, a girl). In this case, Dita Oeprianto and Puji Kuswati are husband and wife; meanwhile the rests are their children.

On Sunday morning, Yusuf Fadhil and Firman Halim went to Church Santa Maria Tak Bercela at Ngagel MadyaStreet 1 by motorbike. Both carried bomb by putting it in his lap. They entered the church gate at around 07.13 WIB, they were stopped by Bayu, a volunteer as the church security guard. Those boys drove the motorbike quite fast and forced to enter the front yard of the church, Bayu pulled the motorbike, the boys and their motorbike fell down, then the bomb exploded. This explosion killed six people including the bombers and Bayu as well as the church attendees, and injured 30 people. The bombexploded very strong and damaged the front part of the church (Interview with Lauren, a management staff of Church Santa Maria Tak Bercela, and observation on the site, 16 May 2018).

Puji Kuswati (the mother) and her two daughters (Fadhila Sari and Famela) were dropped by Dita Oepriarto (father) using an "avanza" car in front of the church. Then, the mother and her daughters enter to church GKI at Diponegoro Street. Puji Kuswati carried a bag containing bomb, while those two kids carried bombs tied as their belt. At around 07.50 WIB, these three people enter the church through the unusual route for the pedestrian, so that they were stopped by the security guard and asked, "what purpose do they enter the church?", Puji Kuswati answered "I am sorry, Allahu Akbar" and then suddenly the bomb exploded. This explosion caused Puji Kuswati and her children died and injured many people there. This incident did not caused death of the parishioners (Interview with, Yossua, the board member of GKI Church, 16 May 2018).

After dropping his wife and his daughters earlier, Dita Oepriarto went to Pantekosta church at Arjuna Street by driving an "Avanza" car containing bombs. He entered the church at 07.50 WIB. At that time, Daniel, a church activist who managed the traffic of worshippers in front of the church, tried to stop the car. After that, the car hit the church gate and did not enter the church, then the car blow up lead to many casualties; there were seven parishioners and the bomber death, many people injured, several motorbikes around the church were burnt, several cars damaged, and the church building were also damage. The bombing in this church can be categorized as a big explosion that caused serious properties damage, many wounded persons and death (Interview with Awal Soediono, GPPS church board member at Arjuna Street Sawahan Surabaya, 16 May 2018).

According to the coordinator of public relation regional police East Java, Police grand commissioner F Barung Mangera, S.I.K, the suicide bombers are associated with the Jamaah Ansyarud Daulah (JAD) cell in Surabaya. This group is closely related with the JAD- 
JAT (Jemaah Ansharut Tauhid), groups that supported ISIS. Even, Dita Opriarto was known as the leader of JAD Surabaya. Furthermore, F Barung Mangera mentioned that involving family in the terrorism is a new strategy of JAD terrorism, the daily performance of the terrorists are the same as other people in their neighborhood.They wear their cloth as other Muslim fellow, Dita Oprianto do not have beard, as it is usually common for people involving in the radical group having beard. His wife was also wearing the common Muslim women have, she did not wear niqab that covered all her face except her eyes. They interacted with people around them in their neighborhood and participated in the social activities in their area, so that they were not exclusive. Even, they were known as "good and friendly" neighbors by their surroundings (Interview with F. Barung Mangera, 16/05/2018, and interview with several of Dita Oprianto's Neigbors, 19/05/2018).

After the bombing blast at those three churches, there is further bomb explosion at the late evening (around 9 PM) at the same day, on Sunday 13 May 2018 at Wonocolo-Low-cost apartment in Sidoarjo, East Java, which is about $16 \mathrm{KM}$ far from the downtown of Surabaya. According to people (eyewitnesses) living in that place, the first explosion happened at 18.30 WIB (Western Indonesian Standard Time). That explosion came from the unit occupied by Anton Febrianto's (47 years old) family at the fifth floor of Block B. They thought that the explosion caused by gas cylinder which is usually for cooking, Residents at that place wanted to try to help them, then they saw three people laid on the floor covered by blood and some cables at that house, they suspected that it was bomb. Then they did not help them, and made a phone call to police office, few minutes later many polices along with the Densus 88 and Gegana team came to that place. At that time, Anton Febrianto was alive; he held the bomb igniter and tried to fight against the police. Then, the police shoot dead Anton Febrianto at that place (Interview with the Eyewitness, 18 May 2018). According to the police, such bomb at that house will be exploded at other places, but it was prematurely exploded. Later, it was known that Anton was a close friend of Dita Oprianto, the actor of bombing at GPPS church. Both are affiliated with JAD.

The explosion at that place caused three people died namely; Anton Febrianto, his wife named Puspita Sari (47 years old), and his daughter named Hilta Aulita Rachman (17 years old). This explosion led to two children of Anton Febrianto, injured namely the daughter (11 years old) and the son (10 years old). These two children were sent to Khadijah hospitals for treatment, and then they were sent to Bhayangkara hospital. Meanwhile, another of his son was safe, since he was not home at the time of incident.

On Monday morning, 14 May 2018, another bombing was detonated at the front gate of metropolitan Police Office of Surabaya East Java. This was happened just one day after the previous incident; it looks like a series of planned actions. From the recorded video of CCTV, it was seen that there were five people, they rode two motorbikes. On the first motorbike, there were two people and one kid sat at the front. Meanwhile on the second motorbike, there were two people. When they arrived at the front gate, at the check point, the first explosion happened from the first motorbike, and then it was followed by the second bomb blast coming from the second motorbike just in few second.

All those five terror actors are coming from one family, Tri Murtiono (51 years old), Tri Ernawati (44 years old) the wife of Tri Murtiono, and their children namely MDAM (20 years old), MDSM (16 years) and AAP (8 years). At that time, APP was carried out on the first motorcycle and flung away on the floor but he was safe. On the other hand, all those four people death on the crime scene. This incidence caused four polices and six people were injured because of that two bombs blast. Furthermore, it is known that Tri Murtiono is a friend of Dita Oepriarto, the bomber of Pantekosta church. 


\subsection{The Involvement of Women and Children in Terrorism}

The involvement of women and children within a family as a bomber is new phenomenon in Indonesia. It has never done before; one family consisting father, mother, and children committed a joint bombing. In many previous bombings in the country, bombing has always been carried out by men. There was a woman named Dian Yulia Novi who planned to explode bomb in Bekasi West Java known as pan bombing in 2016, but this was failed. She would explode it by herself without any children or family. Thus, the involvement of women and children as the actor of bombing was a new phenomenon in Indonesia. But this is not new in other countries, as there are several bombing cases in several countries. For instance, women are mostly involved as the actors of terrorism. From 2000 to March 2007 there were 46 of 110 of the actors were women [3].

Related to how people are willing to participate in the terrorism, [6] describes that to become a terrorist there are five ladder conditions that must be passed. Initially, the individual interprets the material condition; on the first step, individuals look for solutions about what is perceived as unfair treatment; then, in the second step, the individual builds physical readiness to solve the problem by attacking "the enemy". Those people who are actively looking for opportunities to launch attacks increase at a later stage, namely taking action against those who are considered enemies. On the third step, individuals identify themselves by adopting the moral values of their group. The crucial developments are on this third ladder to the fourth ladder, in which someone enters a terrorist organization, and there is only a small possibility or even no chance to get out alive. The fifth stage, the individual are psychologically ready and to commit of terrorism [6].

That Mogadham's view can be used to look at how and why women and family are involved in the front line of terrorism. The first, a father is influenced by radical thought and he has experienced of what Mogadham's said, then he will transfer his knowledge and experience to his wife and his children. Furthermore, he will invite his wife and his children to participate in the action which is labeled as jihad, or fighting against their enemies. Moreover, one of the characters of terrorism is persistence, in which they will struggle continuously and ready to take any challenges and risks their life until they achieve their goals. With this persistence character, the leader of terrorists constantly trains their members and forms cadres. They also use many methods to attract people, so that those people will have interest in terrorism ideology. Once those people are influenced by such ideology, they will voluntarily participate in bombing actions disregarding the ethic of humanity values [7].

Women engagement on the front line of terrorism in Surabaya Indonesia was almost similar with the idea of women or wife as the second commander of jihad after her husband. It was told in Saputro's article that Paridah's story, the wife of Ali Ghufron, one of the Bali Bombers 1, mentioned that the roles of women in the Islamic radical group are as the good wife and teacher of their children. In this sense, women's roles are mostly on the domestic sphere. However, the wives actively support their husband on doing jihad, or committing violence actions. The husband holds the central role in the family and plays as the commander during jihad. Once their children grown up, the wife might become the second commander which will be ready to go to the battle field with her husband at anytime when it is needed by their group. Then the wife will commit suicide bombing as her husband command [3].

In the past, the wives of terrorist commonly take a part in the domestic space; as a wife, nurturing and teaching their children. The wife will educate their children and made their father who commits terror actions as their idol. A woman especially a wife plays important role in this stage, since a mother will easily transmit any ideologies including radical thought 
to her children. The character of women, feminine, will easily reach their children and convince them about values that need to be affirmed; therefore children will hold those values robustly. Gender segregation that differentiates man and women roles, make women easily transforms any values to their children, and these values are going to influence the children during their grown up [8].

The wife's mental attitudes were influenced by the doctrines thought by her husband or her ustadz (Islamic teacher) who is usually the leader in the group's network. As it is the fact that the culture of Jihadist group, there are two types of patriarchal commando namely the husband and the ustadz. In the structure of Jamaah Ansyarud Daulah (JAD) who is affiliated with ISIS, each member has to have readiness to do "istisyhad" (readiness to die as a "bride" or bomber). From the beginning, the doctrine spread to the members is jihad meant qital (war) that is the main compulsory. This doctrine is placed higher than other religious services like prayer, fasting, and hajj. Thus, death during the war should be the main goal of each member of the group. Hence, an opportunity to be a bomber is their dream, and they will be selected to do such action when their leader picks them as the bombing actor [9].

There is a doctrine told to women/wife in this group network that in Islam there are women heroes as mentioned in the classic literature; for instance, during the Prophet Muhammad's time, there were many women involved in the jihad with their bravery. To name some of those women are Aisyah (the daughter of Abu Bakar), Safiyyah, Hafsah (the daughter of Umar bin Khatab), Nusyaiba (Umm 'Umara), and other women. The life history of those women was told repeatedly as part of the doctrine, so that it will encourage women in the group to be engaged in the jihad. This teaching is in accord with the fatwa that jihad is compulsory for men and women because the "Islamic" nations in the world are weak.

The involvement of women and their children in the bombing action in Surabaya and Sidoarjo depicted that women played significant role not only as the main actor of terrorism but also as the inviter of the bombing action to their children. This is a fact that woman is effective to reach her terrorism goal for the following reasons; firstly, women are perceived as having effective skill in transmitting radical thought in the family especially to their children. This is in line with the role segregation between men and women in which woman has domestic tasks teaching and nurturing their children. The radical thought was transmitted through family education. Secondly, many studies show that women are less suspected than men. Bloom [10] mentioned that most security officers did not frisk women when they enter certain place or crossing the border. If there is a frisk toward woman, the terrorist group will use it as propaganda that the security officer harassed a woman. In addition, the involvement of women in the suicide bombing is one of the ways to attract media attention, since a terrorist group needs media spotlight as part of their propaganda. Hence the affectivity of female suicide bomber is a way to draw media coverage. Bloom [10] said that media exposed female terrorists eight times more than male terrorists. Moreover, during their operation women clothing can hide the weapon including bomb like hiding in her belt, her bag, and her back pack.

Thirdly, multipurpose; the involvement of women in the terrorism might have various roles namely; recruiter of new members including her children, finance manager, providing budget and logistic, propagandist, messenger for enemy attacking, helping to hide terrorist escapee, clandestine activities to support their terror actions, collecting information of target of terror attack and movement of the security, as well as played as the suicide bomber. Thus, women are considered as effective and efficient strategy for terrorism.

Women as the actor of terrorism then contradict with the idea of sex and gender system offered by Radical feminist which said that sex and gender is the main source of 
women oppression. As a result, women are placed as an inferior class, sub-ordinate and below the patriarchal values [11]. The case of Surabaya and Sidoarjo proofs that women were able to be the main actor and to mobilize their family to commit suicide bombing. This research shows that women have power to transmit radical thought in the family and to determine the family values.

Why are women interested in joining a terrorism network, even becoming bombers as found in this study? Poole (2002) found that many Muslim women joined ISIS because they believed that ISIS offered a new religious ideology that was free from thoghut, or the enemy of God. By avoiding it, they will find the meaning of life, especially finding for justice. This sentiment strengthens in women, because women are a group in society who feel the most injustice. Therefore, it is time for women to fight against injustice by joining the terrorist network.

There are implications for the family if women become important figures of terrorism group, they will carry out their domestic roles and internalize the values in the family including the radical thought. Then, the terrorist family network began to form; women will start to invite family members, husbands and children to join. After that, they will invite their relatives. It seems that the use of the family is a shortcut in the radicalization process. All of the women bombers as found in this study invited and involved their families. Brotherhood in the family is the most effective method in forming a terrorist network. This is because the psychological influence that can bind and strengthen each other. With this method they not only become members of terrorist groups, but also become brothers and sisters (a relative). Furthermore, involving families in the terrorism through marriage is also easier way because the process of building trust is easier than with strangers or other unfamiliar people.

\section{Conclusion}

Bombing in Surabaya and Sidoarjo East Java Indonesia caused 25 people death consisting of 11 bomber and 14 people of victims. This case also injured many people and damaged properties at the scene and its surroundings. Actors of these cases are family members including father-mother-children. In addition, these people are affiliated with JAD, an organization that support ISIS. In this terror action women and children were actively engaged as actors. These cases show that women played significant roles in the jihadist group, not only as the main actor but also as the inviter of their children. In addition, their involvement as the fighters was a part of their support to their husband as the jihadist. The position of women in a terrorist group is actually vulnerable in which they are most likely to be involved in the terror activities. It is the fact that environment will influence their acts and behaviors. In this sense, women have to abide by their husband and they will have difficulties to reject the invitation to be engaged in terrorism actions. At the same time, women might have power to influence their children and to invite them to do terror actions. Besides, women in this group were also influenced by religious teaching given by the group leader or ustadz in the group. That is why women will have willingness to take a part in the terror actions.

As women now are involved in the front line of terrorism, it will give benefit to the terrorist group, for instance; they will get media exposure as this is part of their strategy to attract world's attention. In addition, one of the terrorism goals is spreading fear to the people; hence the continuous media coverage on their terror will make people afraid. Therefore, women in the group can be said that they played both in domestic and "public" space; managing their family, nurturing their children, and bombing actor. 


\section{References}

[1] A. Farida, A. J. Wahab, and Zakiyah, "Laporan Penelitian Kasus Bom Surabaya dan Sidoarjo 2018," Jakarta, 2018.

[2] Tempo.co, "Penjual Airsoft Gun Istri Terpidana Teroris," www.nasional.tempo.co, 2013. .

[3] M. E. Saputro, "Probabilitas Teroris Perempuan di Indonesia," JSP J. Ilmu Sos. dan Ilmu Polit., 2010.

[4] A. Utama, "Hamil tua, calon 'pengebom bunuh diri' Istana Presiden minta segera divonis," www.bbc.com, 2017. .

[5] D. Purnama, "No TitleTerungkap, Ika Puspitasari Calon 'Pengantin' yang Akan Ledakkan Bom di Bali," www.okezone.com, 2016. .

[6] F. M. Moghaddam, "Psychological processes and 'the staircase to terrorism,"' American Psychologist. pp. 161-169, 2005.

[7] R Hrair Dekmejian, Islam in revolution: fundamentalism in the Arab world, 1st ed. New York: Syracuse, N.Y. : Syracuse University Press, 1985.

[8] M. Maynard and S. Walby, "Theorizing Patriarchy,” Br. J. Sociol., 1992.

[9] Mohammad and M. O. Mohamedoue, A Theory of ISIS Political Violence and Transformation of the Global Order. London: Pluto Press, 2018.

[10] M. Bloom, "Bombshell: Women and Terrorism," Oxford Res. Encycl. Polit., 2017.

[11] S. Firestone, The Dialectic of Sex The Case for Feminist Revolution. 1971. 